\title{
WPŁYW ROZKŁADU OBCIAZŻENIA EKWIWALENTNEGO NA ZACHOWANIE MEMBRANY MODELUJĄCEJ ZBROJENIE WARSTWY TRANSMISYJNEJ
}

\author{
Beata Gajewska ${ }^{1 凶}$, Marcin Gajewski \\ ${ }^{1}$ Instytut Inżynierii Lądowej, Szkoła Główna Gospodarstwa Wiejskiego w Warszawie \\ ${ }^{2}$ Wydział Inżynierii Lądowej, Politechnika Warszawska
}

\begin{abstract}
STRESZCZENIE
Rozkład obciążenia zastępczego w analizie zbrojenia warstwy transmisyjnej nasypów na słabym podłożu wzmocnionym kolumnami ma wpływ na zachowanie membrany modelującej to zbrojenie. W zależności od modelu obliczeniowego powszechnie stosowane są rozkłady trójkątny, równomierny i odwrotny trójkątny. W pracy przeanalizowano zachowanie membrany pod wpływem 11 różnych rozkładów obciążenia. Dla wszystkich rozkładów wyznaczono krzywe ugięcia oraz wykresy sił rozciągających, odkształceń i kąta obrotu membrany dla zadania modelującego eksperyment w skali rzeczywistej. Przeprowadzono także analizę wpływu współczynnika sztywności $k$ słabego podłoża między kolumnami oraz sztywności zbrojenia na zachowanie membrany. Stwierdzono, że przyjęcie jednego z rozkładów jako odpowiedni w każdej sytuacji projektowej nie zawsze jest uzasadnione. W pracy wykazano, że stosunek odporu gruntu do sztywności zbrojenia ma istotny wpływ na charakter funkcji i wartości ekstremalne sił wewnętrznych, odkształceń i ugięć. W wyniku przeprowadzonych analiz wykazano, że zwiększanie sztywności gruntu (parametr k) zmienia w sposób istotny charakter funkcji ugięcia, odkształcenia i siły normalnej w membranie, a zmiana ta zależy od rozkładu obciążenia zastępczego.
\end{abstract}

Słowa kluczowe: kolumny sztywne, warstwa transmisyjna, zbrojenie warstwy transmisyjnej, zachowanie zbrojenia, izotropowe membrany

\section{WSTĘP}

Występowanie w podłożu gruntów słabych wymusza stosowanie rozwiązań zapewniających bezpieczeństwo konstrukcji, przy jednoczesnym minimalizowaniu kosztów jej wznoszenia. Nasypy na słabym podłożu wzmocnionym kolumnami są powszechnie wykorzystywane w budownictwie komunikacyjnym. Słabe podłoże wzmacniane jest z użyciem kolumn sztywnych. $\mathrm{Na}$ tak wzmocnionym podłożu formowana jest warstwa transmisyjna, która zwykle jest zbrojona, a następnie wznoszony jest docelowy nasyp. Obciążenia od nasypu i ruchu pojazdów są przekazywane zarówno na kolumny, jak i słaby grunt między kolumnami oraz zbrojenie. Rozdział obciążenia następuje w wyniku przesklepienia w gruncie (tzw. arching effect). Istnieje wiele modeli tego zjawiska (Hewlett i Randolph, 1998; Zaeske, 2001; Van Eekelen, Bezuijen, van Tol, 2013).

Analiza zbrojenia warstwy transmisyjnej wykonywana jest w dwóch krokach. W pierwszym kroku następuje rozdział obciążenia na część przenoszoną przez kolumny i część przenoszoną przez zbrojenie i słaby grunt. W kolejnym kroku wyznaczane są siły i odkształcenia w zbrojeniu. Cała konstrukcja to układ przestrzenny z wieloma interakcjami elementów systemu. 


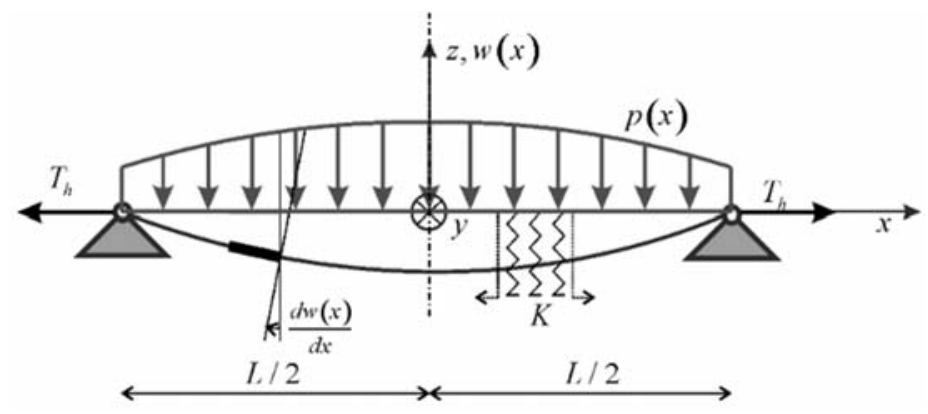

Rys. 1. Membrana modelująca zbrojenie warstwy transmisyjnej

Fig. 1. A membrane modeling the reinforcement of the load transfer platform

W celu wyznaczenia sił i odkształceń zbrojenia układ przestrzenny redukuje się do jednowymiarowego. Zbrojenie modelowane jest jako izotropowa membrana (Gajewska i Gajewski, 2019a). Obciążenia przekazywane na zbrojenie i słaby grunt między kolumnami sa zbierane, a na jednowymiarowej membranie jest obciążenie ekwiwalentne. Jego rozkład może być różny. Na rysunku 1 przedstawiono go symbolicznie jako funkcję $\widetilde{\rho}(x)$. Trzy powszechnie stosowane rozkłady to: trójkątny (DGGT, 2011), równomiernie rozłożony (BS8006-1:2010) i odwrotny trójkątny (Van Eekelen i Brugman, 2016). Membrana spoczywa na podłożu sprężystym o stałej K, ekwiwalentnej do współczynnika sztywności podłoża $k$ (Van Eekelen, 2015).

\section{MATERIAt I METODY}

W celu znalezienia sił wewnętrznych $\mathrm{w}$ zbrojeniu rozwiązano zadanie rozciągania jednowymiarowej membrany z układem współrzędnych tak przyjętym, aby wykorzystać symetrię zadania (rys. 1). Rozwiązanie tego zadania istotnie różni się od rozwiązania typowej membrany w ramach teorii małych przemieszczeń i odkształceń, gdyż w przypadku szacowania stanu odkształcenia rezygnuje się $\mathrm{z}$ założenia małych odkształceń, w zamian wyrażając je za pomocą wzoru na długość łuku. Wprowadza to do zadania nieliniowość relacji geometrycznych, co istotnie utrudnia znalezienie rozwiązania analitycznego zadania (istnieje ono tylko $\mathrm{w}$ przypadku obciążenia równomiernego). W związku z tym konieczne jest zastosowanie metod przybliżonych typu analitycznego bądź numerycznego. Przedstawione w tej pracy rozwiązania wykorzystują wcześniejsze wyniki zamieszczone m.in. w opracowaniu Gajewskiej i Gajewskiego (2019b). W ramach poszukiwania rozwiązania przybliżonego zadania rozciagania izotropowej membrany zaproponowano tam rozwinięcie wyrażenia na długość łuku w szereg Taylora oraz rozwiązanie nieliniowego równania zgodności odkształceń przy zastosowaniu metod numerycznych. Do wykonania obliczeń symbolicznych, numerycznych oraz sporządzenia wykresów zastosowano program Wolfram Mathematica. Metodyka ta w całości jest wykorzystywana w niniejszym artykule. W pracy Gajewskiej i Gajewskiego (2019b) przeanalizowano wpływ liczby wyrazów szeregu na dokładność uzyskiwanego rozwiązania, wskazując, że już przy 15 wyrazach szeregu uzyskuje się zadowalającą dokładność określania ugięć, odkształceń i sił wewnętrznych w membranie. Wobec tego w celu znalezienia rozwiązań przedstawionych dalej przykładów wyrażenie na długość łuku rozwinięto w szereg Taylora o 15 wyrazach.

Do analizy zachowania membrany wybrano zadanie opisujące eksperyment w skali naturalnej (Almeida, Ehrlich, Spotti i Marques, 2007; Almeida, Marques, Almeida i Mendonca, 2008). Przekrój i widok z góry stanowiska badawczego pokazano na rysunku 2. Rozstaw kolumn zwieńczonych kwadratowymi czapkami o boku $0,8 \mathrm{~m}$ wynosi $2,5 \mathrm{~m}$. Przed ułożeniem zbrojenia geosyntetycznego pomiędzy kolumnami wykonano jednometrowy wykop.

Czas obciążenia nasypem wynosił 188 dni. Nasyp wykonano $\mathrm{z}$ gruntu o ciężarze objętościowym równym $18 \mathrm{kN} \cdot \mathrm{m}^{-3}$. W przeprowadzonych badaniach (Almeida i in., 2007, 2008) wykazano, że grunt nasypu charakteryzuje się następującymi parametrami: średni 

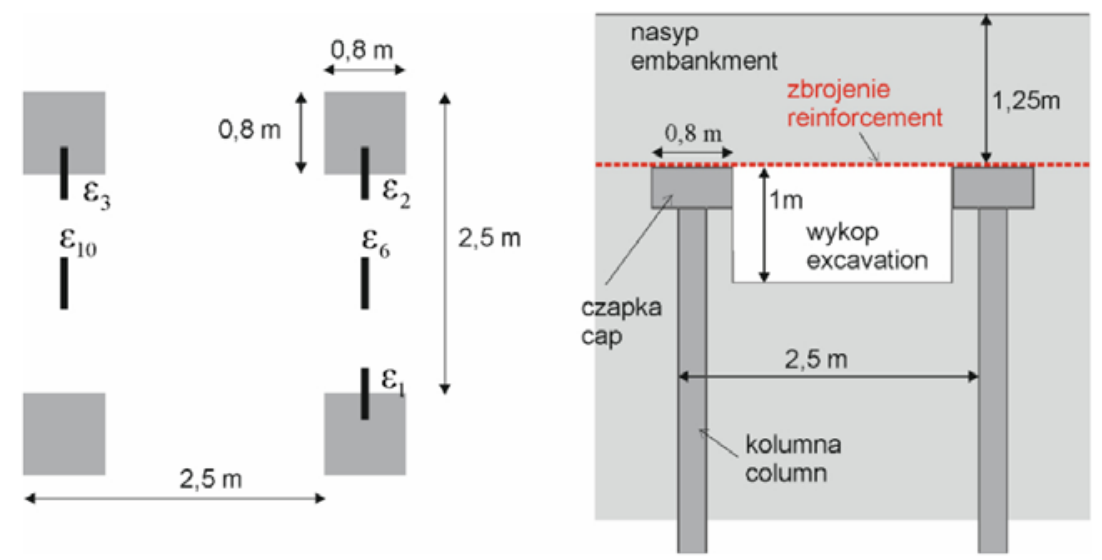

Rys. 2. Schemat stanowiska badawczego w skali naturalnej wraz z rozmieszczeniem wybranych czujników przemieszczeń (numeracja czujników jak w eksperymencie) na podstawie Almeida i in. (2007, 2008)

Fig. 2. Scheme of full scale research stand with the arrangement of selected strain sensors (sensor numbering as in the experiment) on the basis of Almeida et al. $(2007,2008)$

kat tarcia wewnętrznego $\varphi=43^{\circ}$ i średnia spójność $c=18,9 \mathrm{kPa}$. W modelach obliczeniowych przyjęte jest założenie, że grunty nasypu są niespoiste. Do celów projektowych spójność jest pomijana. Jednak do analizy zachowania membrany uwzględniono wpływ spójności. Przyjęto zastępczy kąt tarcia wewnętrznego i stosując model CA (Van Eekelen i in., 2013), oszacowano obciążenie zastępcze $q_{a v}=16 \mathrm{kPa}$. Do zbrojenia użyta była geosiatka, dla której sztywność przy 1,5\% odkształceniu po 188 dniach od wbudowania wynosiła $1615 \mathrm{kN} \cdot \mathrm{m}^{-1}$ (Van Eekelen, 2015).

W tabeli zestawiono wyniki pomiarów odkształceń zbrojenia na skraju kolumny (czapki) i między kolumnami.

W analizach zachowania membrany modelującej zbrojenie przyjęto 11 rozkładów obciążenia zastępczego $\widetilde{\rho}(x)$, zmieniając parametr $\delta \mathrm{w}$ funkcji:

$$
\tilde{p}(x)=\frac{2 q_{a v}\left(x(1-2 \delta)+\delta \frac{L}{2}\right)}{\frac{L}{2}}
$$

gdzie:

$q_{a v}$ - ekwiwalentne obciążenie membrany [kPa],

$\delta$ - współczynnik określający rozkład obciążenia [-],

$L$ - odległość w świetle między kolumnami [m].

Parametr $\delta$ był zmienny w zakresie od 0 do 1 . Dla $\delta=0$ obciążenie przyjmuje rozkład odwrotny trójkątny, dla $\delta=0,5$ rozkład równomierny, a dla $\delta=1$ rozkład trójkątny. Na rysunku 3 pokazano wszystkie analizowane rozkłady obciążenia dla połowy rozpiętości między kolumnami (punkt $x=0$ oznacza środek rozpiętości membrany, podczas gdy przy $x=L / 2$ membrana jest podparta przez kolumnę).

Tabela. Wybrane wyniki pomiarów odkształcenia zbrojenia w eksperymencie zaprezentowanym w publikacjach Almeidy $\mathrm{i}$ in. $(2007,2008)$

Table. Selected measurement results of reinforcement strains in experiment presented in publications by Almeida et al. (2007, 2008)

\begin{tabular}{|c|c|c|c|c|}
\hline \multicolumn{3}{|c|}{$\begin{array}{l}\text { Na krawędzi czapek } \\
\text { On the edge of the caps }\end{array}$} & \multicolumn{2}{|c|}{$\begin{array}{l}\text { Pomiędzy kolumnami (czapkami) } \\
\text { Between the columns (caps) }\end{array}$} \\
\hline$\varepsilon 1$ & $\varepsilon 2$ & $\varepsilon 3$ & $\varepsilon 6$ & $\varepsilon 10$ \\
\hline $2,05 \%$ & $1,73 \%$ & $1,50 \%$ & $1,50 \%$ & $1,36 \%$ \\
\hline
\end{tabular}




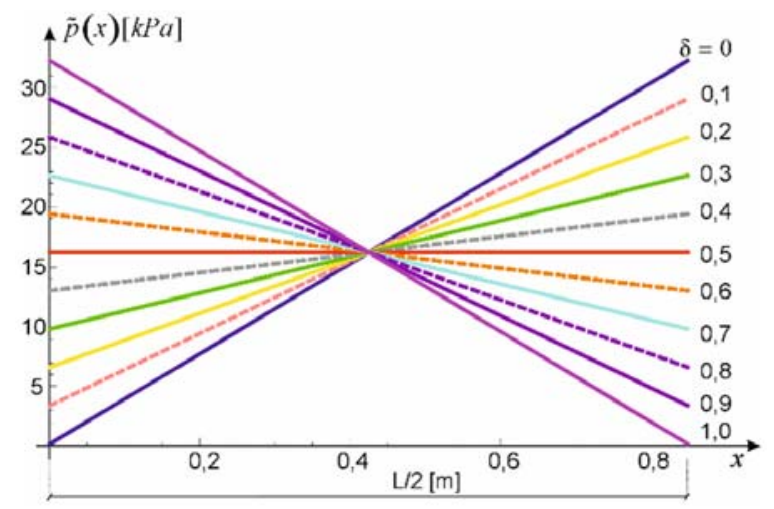

Rys. 3. Analizowane rozkłady obciążenia zastępczego w zależności od parametru $\delta$ dla połowy rozpiętości między kolumnami

Fig. 3. Analyzed equivalent load distributions depending on the $\delta$ parameter for half clear space between columns

Dla wszystkich analizowanych rozkładów wyznaczono funkcje sił i odkształceń zbrojenia, funkcje kąta obrotu i krzywe ugięcia. Poza wyznaczonymi funkcjami dla danych modelujących eksperyment wykonano analizę parametryczną w celu ustalenia wpływu odporu podłoża i sztywności zbrojenia na zachowanie membrany.

\section{WYNIKI I DYSKUSJA}

Dla założonych danych obliczono odkształcenia zbrojenia. Na rysunku 4 pokazano wyznaczone wartości odkształcenia membrany dla przyjętych danych na tle

a

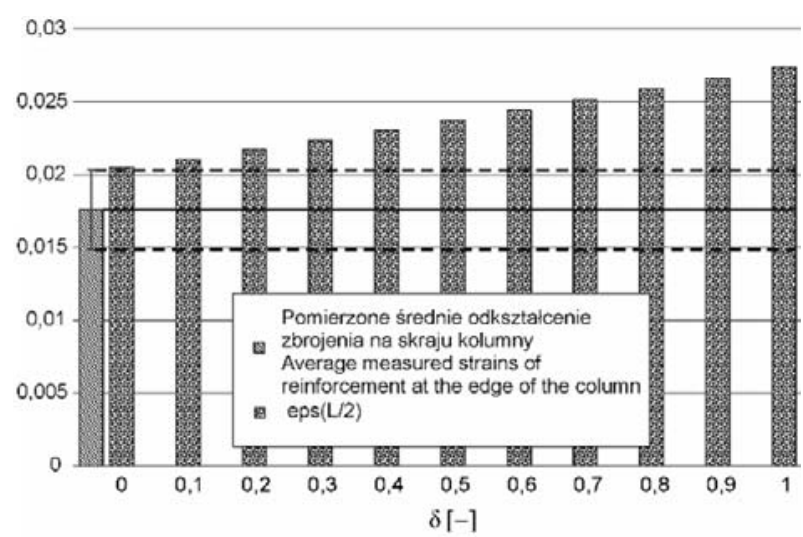

średniego pomierzonego $\mathrm{w}$ eksperymencie odkształcenia na skraju czapki (rys. 4a) i w połowie rozpiętości pomiędzy kolumnami (rys. 4b), wyliczonego na podstawie dostępnych wyników badań (porównaj tabelę). Widać, że uzyskano dość dobrą zgodność wyników obliczeń ze średnią z pomierzonych odkształceń. W każdym przypadku odkształcenia są większe od pomierzonych. Najlepszą zgodność z pomiarami uzyskano dla obciążenia o $\delta=0$, czyli dla rozkładu odwrotnego trójątnego. Van Eekelen (2015) także wykazała, że w przypadku tego eksperymentu spośród analizowanych przez nią rozkładów: odwrotnego trójkątnego, równomiernego i trójkątnego, najlepszą

\section{$\mathrm{b}$}

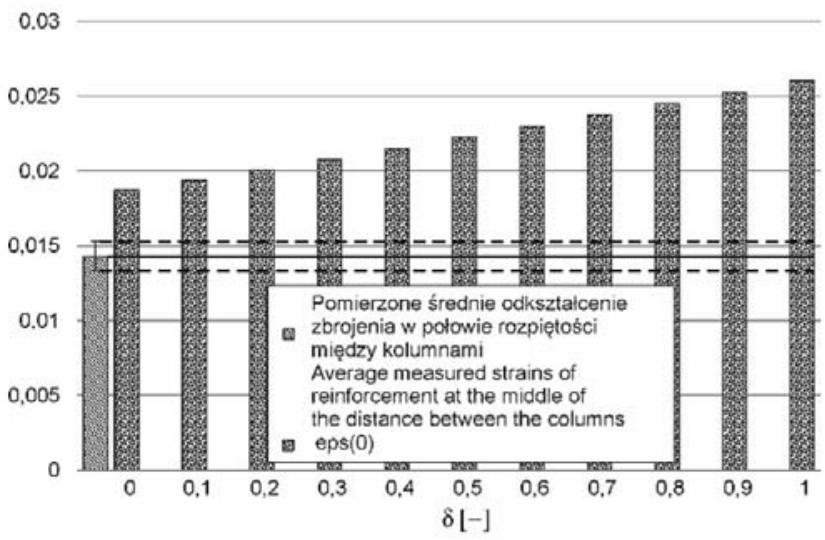

Rys. 4. Odkształcenia membrany na tle średniego odkształcenia wyznaczonego $\mathrm{z}$ pomiarów zaprezentowanych w publikacjach Almeidy i in. (2007, 2008): a - na skraju kolumny (czapki), b - w połowie rozpiętości pomiędzy kolumnami

Fig. 4. Strains of the membrane against the average strain determined from the measurements presented in publications by Almeida et al. $(2007,2008)$ : $a$ - at the edge of the column (cap), b - at the middle of clear space between columns 
Gajewska, B., Gajewski, M. (2020). Wpływ rozkładu obciążenia ekwiwalentnego na zachowanie membrany modelującej zbrojenie warstwy transmisyjnej. Acta Sci. Pol. Architectura, 19 (2), 41-50. doi: 10.22630/ASPA.2020.19.2.16

zgodność z pomiarami uzyskuje się przy zastosowaniu rozkładu odwrotnego trójkątnego.

$\mathrm{Na}$ rysunku 5 pokazano zachowanie membrany w zależności od rozkładu obciażenia i wpółczynnika sztywności podłoża $k$. W przypadku gdy $k=0$, maksymalne ugięcie membrany jest najwieksze $\mathrm{w}$ środku rozpiętości pomiędzy kolumnami. Wraz ze wzrostem współczynnika $k$ można zaobserwować zmianę charakteru funkcji ugięcia membrany w zależności od rozkładu obciążenia.

$\mathrm{W}$ analizowanym przypadku dla $k=25 \mathrm{kN} \cdot \mathrm{m}^{-3}$ uwidocznia się charakterystyczne przegięcie krzywej ugięcia (rys. 5b) dla dwóch rozkładów przy $\delta=0$ i $\delta=0,1$. Maksymalne ugięcie membrany nie występuje już $\mathrm{w}$ środku rozpiętości $(x=0)$, tylko przesuwa się w stronę kolumny. Maksymalnemu ugięciu odpowiada zerowy kąt obrotu membrany (rys. 6b). Wraz ze wzrostem wartości współczynnika sztywności $k$ przesunięcie ekstremum krzywej ugięcia występuje dla rozkładów reprezentowanych przez kolejne wartości $\delta$. W przypadku większych wartości współczynnika $k$ (50 i $75 \mathrm{kN} \cdot \mathrm{m}^{-3}$ ) widoczne jest wyraźnie uwypuklenie krzywej ugięcia w przypadku rozkładów dla $\delta=0$, $\delta=0,1, \delta=0,2$. Podobne zachowanie zbrojenia zaobserwowali Briançon i Simon (2012) w eksperymencie w skali naturalnej, gdzie w podłożu znajdował się grunt o znacznej wartości współczynnika sztywności $k$.

Gdy $k=0 \mathrm{kN} \cdot \mathrm{m}^{-3}$, membrana ugina się maksymalnie $\mathrm{w}$ środku rozpiętości niezależnie od rozkładu obciażenia zastępczego. Wraz ze wzrostem parametru $k$ dla wybranych rozkładów obciążenia zmienia się charakter krzywej ugięcia membrany. Dla $k=75 \mathrm{kN} \cdot \mathrm{m}^{-3}$ maksymalne ugięcie membrany pod obciążeniem reprezentowanym przez $\delta=0$ jest dla $x=0,44$, pod obciążeniem reprezentowanym przez $\delta=0,1$ jest dla $x=0,4$, pod obciążeniem reprezentowanym przez $\delta=0,2$ jest dla $x=0,35$ i pod obciążeniem reprezentowanym przez $\delta=0,3$ jest dla $x=0,25$. a

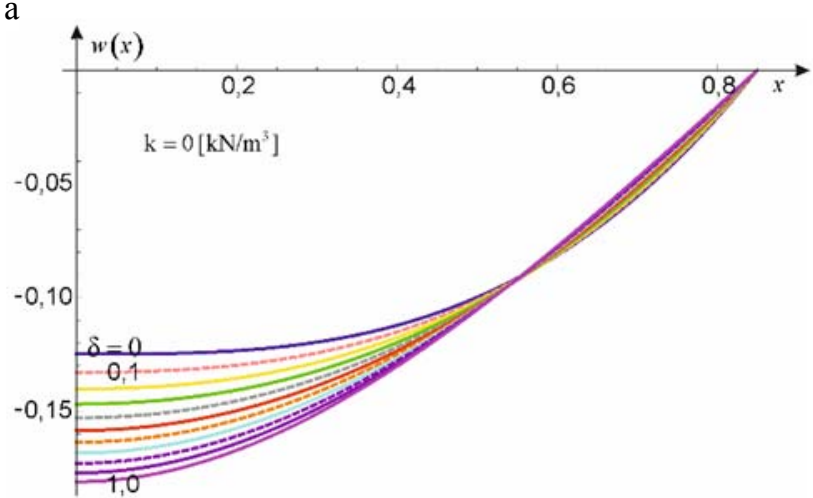

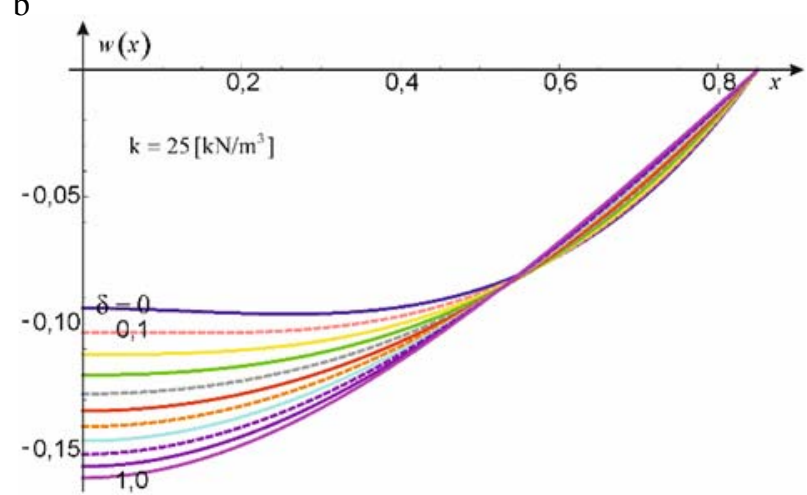

c

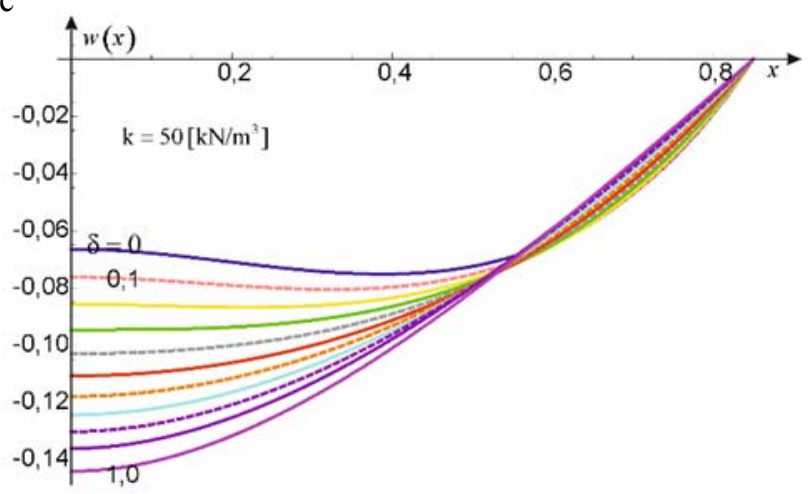

d

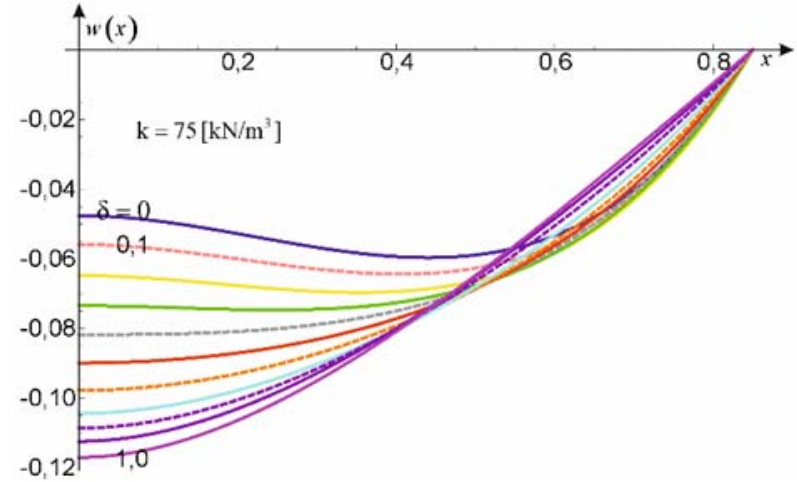

Rys. 5. Krzywe ugięcia membrany dla różnych rozkładów obciążenia zastępczego i dla różnych wartości sztywności podłoża $k$

Fig. 5. Membrane deflection curves for different equivalent load distributions and different subgrade reaction values $k$ 
a

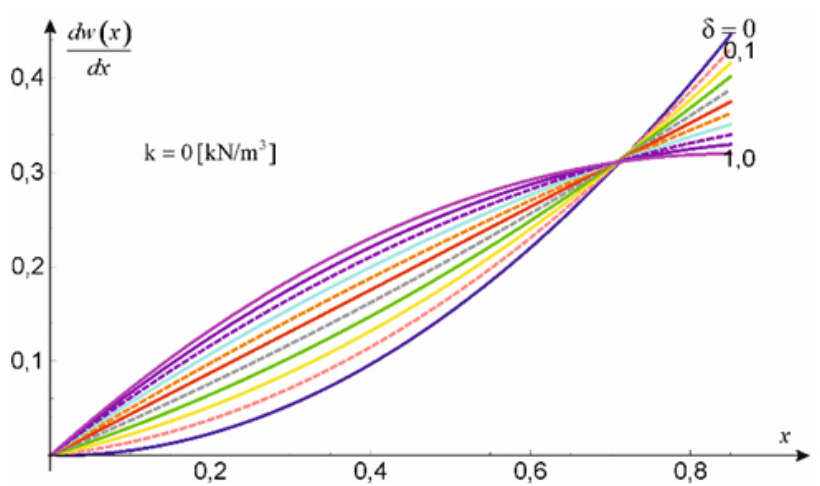

$\mathrm{c}$

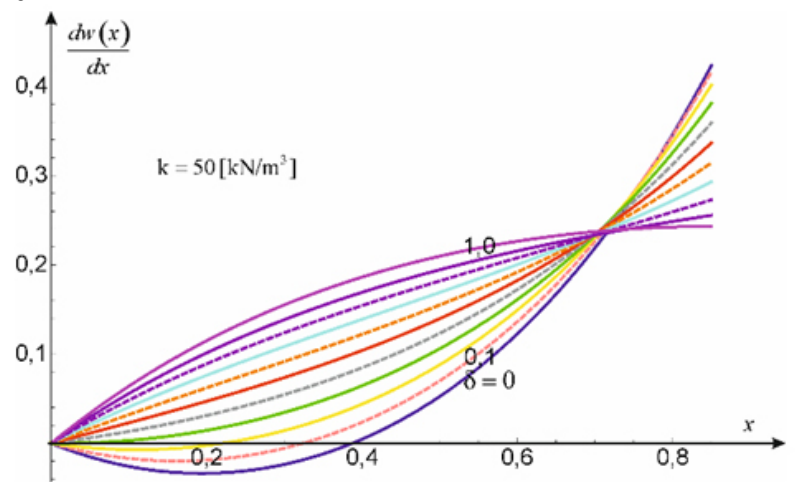

$\mathrm{b}$

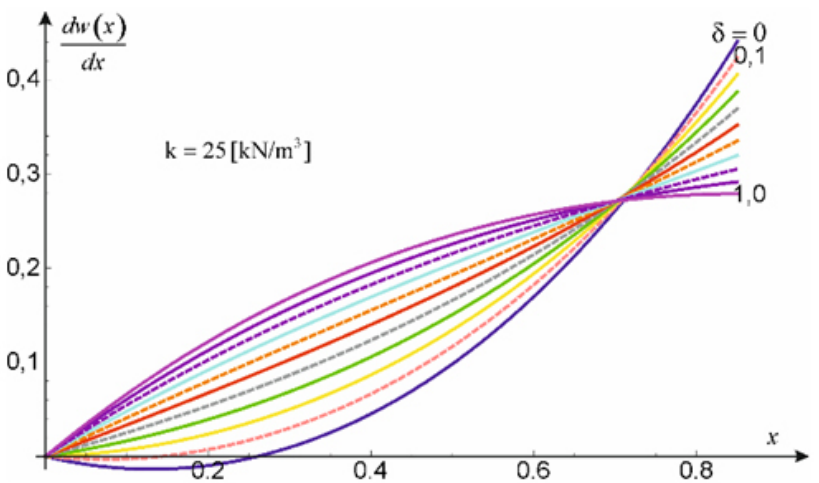

d

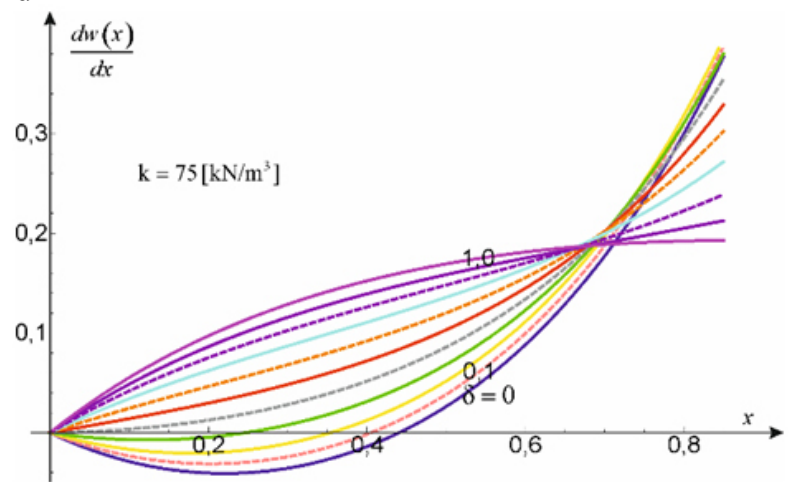

Rys. 6. Kąt obrotu membrany dla różnych rozkładów obciążenia zastępczego i dla różnych wartości współczynnika sztywności podłoża $k$

Fig. 6. Membrane rotation angle for different equivalent load distributions and different values of the subgrade reaction $k$

Dla $k=0 \mathrm{kN} \cdot \mathrm{m}^{-3}$ krzywe kąta obrotu membrany dla wszystkich analizowanych rozkładów przecinają się niemal $\mathrm{w}$ jednym punkcie dla $x \approx 0,7$. Wraz ze zmianą sztywności zbrojenia lub wielkości obciążenia wartość kąta obrotu membrany w tym punkcie zmniejsza się lub zwiększa, lecz nadal dla wszystkich rozkładów obserwuje się punkt przecięcia krzywych kąta obrotu dla $x \approx 0,7$.

Na rysunkach 7 i 8 pokazano siłę w membranie i odkształcenie dla $x=L / 2$ (przy krawędzi) w zależności od rozkładu obciążenia dla różnych wartości współczynnika sztywności podłoża $k$. Dla $k=0$ najmniejsza siła i najmniejsze odkształcenie odpowiada $\delta=0$. Dla $k=50 \mathrm{kN} \cdot \mathrm{m}^{-3}$ najmniejsza siła i najmniejsze odkształcenia na skraju kolumny jest dla $\delta=0,2$, a dla $k=75 \mathrm{kN} \cdot \mathrm{m}^{-3}$ jest dla $\delta=0,3$. Na wykresach tych manifestuje się nieliniowość rozważanego zadania przy znacznych sztywnościach gruntu.
Na rysunku 9 przedstawiono zależność ugięcia membrany w osi pomiędzy kolumnami i siły $T$ dla różnych wartości współczynnika sztywności podłoża $k$ i dla różnych rozkładów obciążenia. Porównując poszczególne wykresy sporządzone dla $\delta \in[0,1]$, można zauważyć, że zwiększanie współczynnika sztywności podłoża $k$ zmniejsza wartość siły normalnej oraz zmienia charakter wykresu. Przy $k=50 \mathrm{kN} \cdot \mathrm{m}^{-3}$ funkcja zmienia się z monotonicznej (dla $k=0 \mathrm{kN} \cdot \mathrm{m}^{-3}$ i $k=25 \mathrm{kN} \cdot \mathrm{m}^{-3}$ ) w funkcję, która $\mathrm{z}$ malejącej przechodzi w rosnącą i osiąga minimum nie na granicy przedziału, ale dla $\delta=0,2$ przy $k=50 \mathrm{kN} \cdot \mathrm{m}^{-3} \mathrm{i} \delta=0,3$ przy $k=75 \mathrm{kN} \cdot \mathrm{m}^{-3}$.

Analizując krzywe odkształceń membrany (rys. 10), można zauważyć, że dla wszystkich analizowanych rozkładów największe odkształcenia membrany są przy głowicy kolumny $(x=0,85)$, a najmniejsze w połowie rozpiętości pomiędzy kolumnami $(x=0)$. 


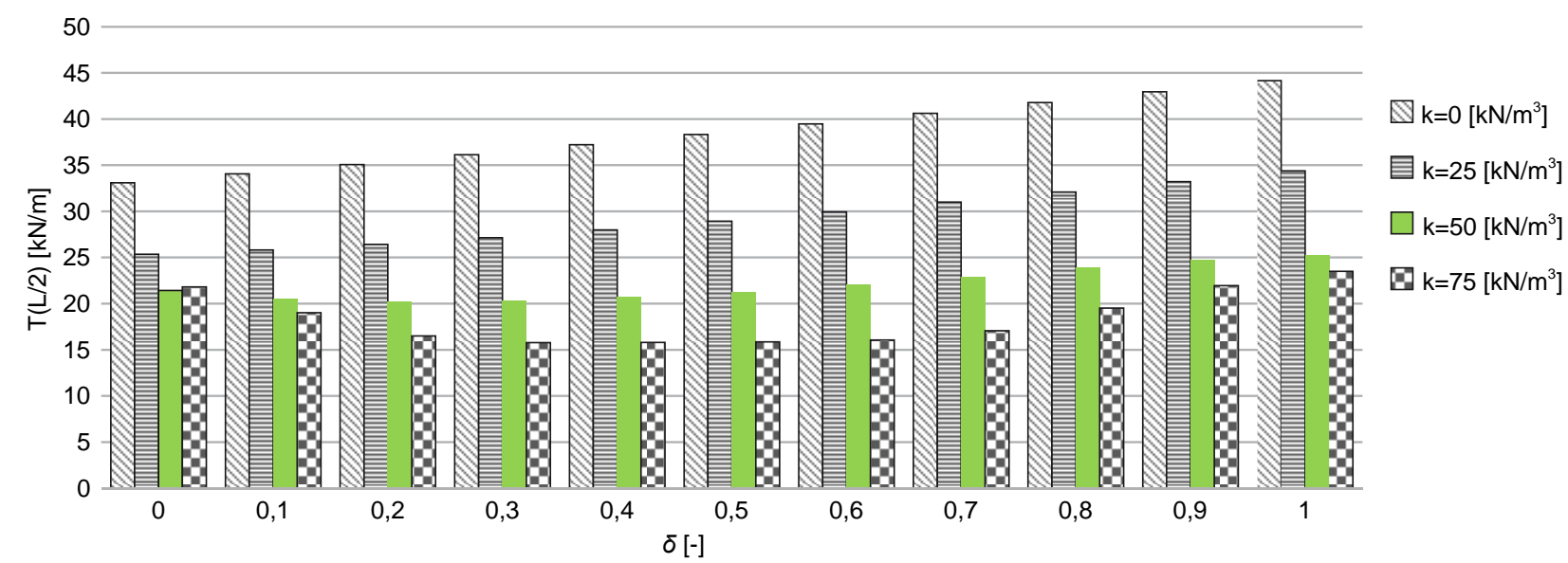

Rys. 7. Siła rozciągająca w membranie przy krawędzi kolumny dla różnych wartości parametru $\delta$ definiującego rozkład obciążenia zastępczego i różnych wartości współczynnika sztywności podłoża $k$

Fig. 7. Tensile force in the membrane at the column edge for different $\delta$ values defining the equivalent load distribution and different values of the subgrade reaction $k$

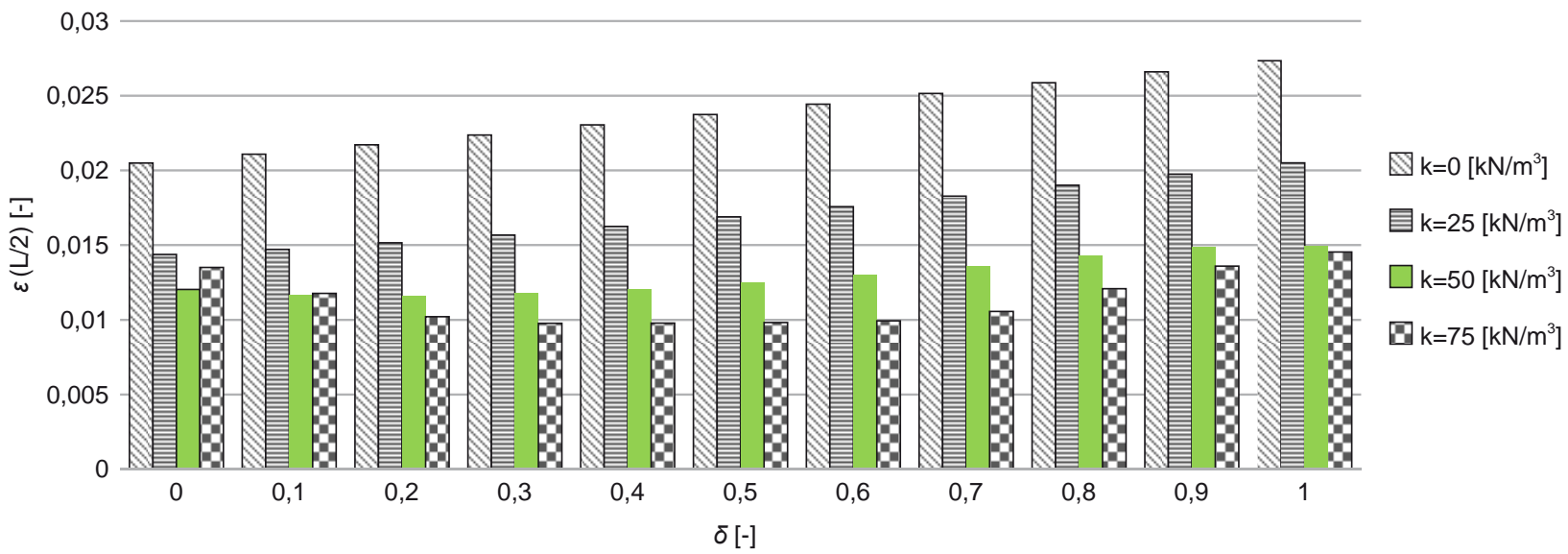

Rys. 8. Odkształcenia membrany przy krawędzi kolumny dla różnych wartości parametru $\delta$ definiującego rozkład obciążenia zastępczego i różnych wartości współczynnika sztywności podłoża $k$

Fig. 8. Membrane strains at the column edge for different $\delta$ values defining the equivalent load distribution and different values of the subgrade reaction $k$

Rys. 9. Zależność ugięcia membrany i siły w połowie rozpiętości pomiędzy kolumnami $(x=0)$ dla różnych wartości parametru $\delta$ definiującego rozkład obciążenia zastępczego i różnych wartości współczynnika podatności podłoża $k$

Fig. 9. Relationship of membrane deflection and the force in the middle of the span between columns $(x=0)$ for different $\delta$ values defining the equivalent load distribution and different values of the subgrade reaction $k$

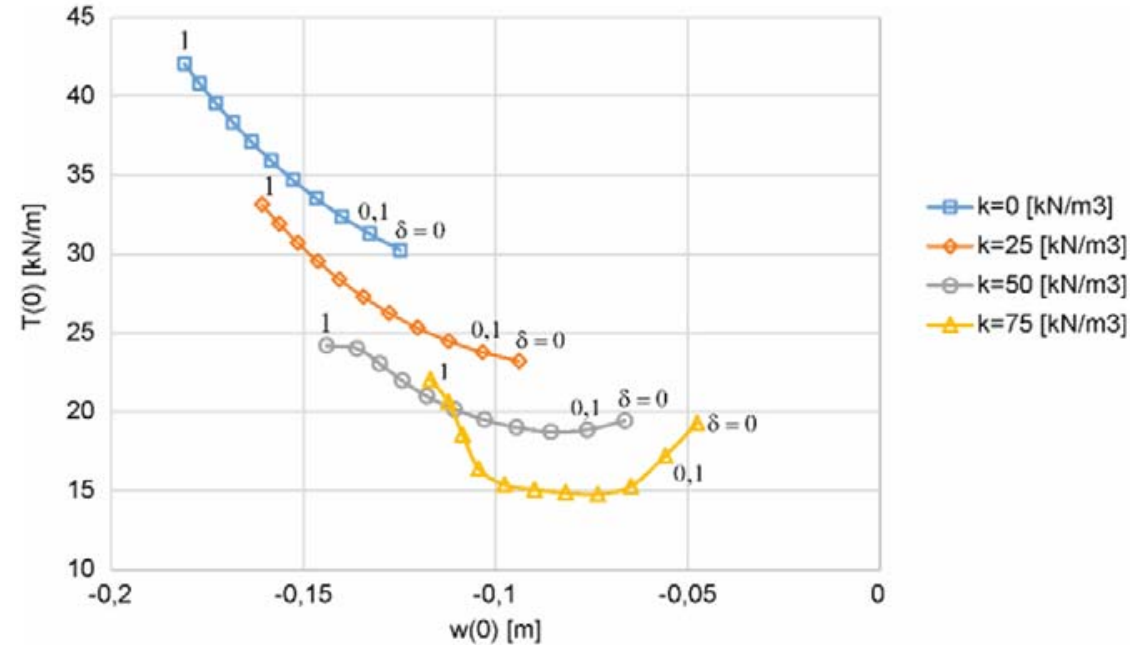


Dla $k=0 \mathrm{kN} \cdot \mathrm{m}^{-3}$ dla rozkładu zastępczego obciążenia reprezentowanego przez $\delta=0$ (rozkład odwrotny trójkątny) odkształcenia membrany są najmniejsze, następnie rosną wraz ze wzrostem parametru $\delta$, a dla obciążenia o $\delta=1$ (rozkład trójkątny) odkształcenia są największe. Jednak dla większych wartości współczynnika sztywności podłoża $k$ najmniejsze odkształcenia membrany są dla rozkładu obciążenia zastępczego o $\delta=0,3$ (por. rys. 10b), dla którego odnotowano najmniejszą wartość siły $T$.

a

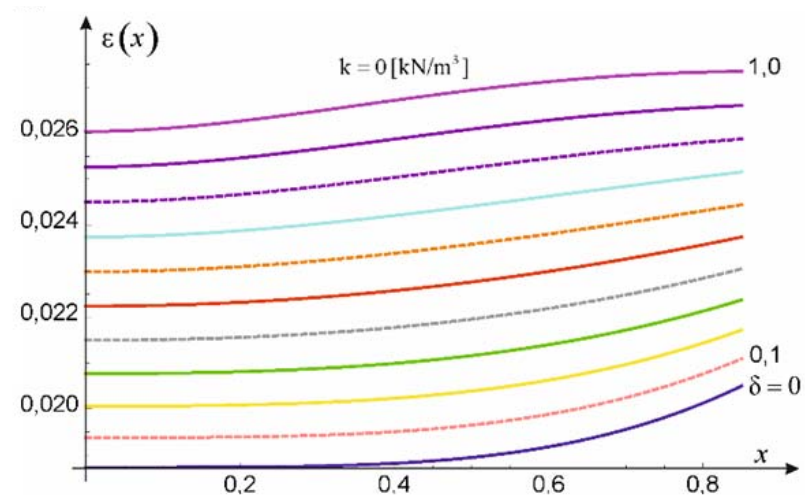

Wraz ze zmianą sztywności membrany charakter zachowania membrany nie ulega zmianie w stosunku do pokazanego na rysunkach 5a i 6a. Membrana ugina się najwięcej w środku pomiędzy kolumnami. Maksymalne ugięcie membrany dla $x=0$ jest najmniejsze dla $\delta=0$ i rośnie wraz ze wzrostem tego parametru. Wraz ze wzrostem sztywności maleje ugięcie membrany dla wszystkich rozkładów obciążenia i zmniejsza się zakres zmienności maksymalnego ugięcia w zależności od rozkładu obciążenia (rys. 11). Jednak dla każ-

b

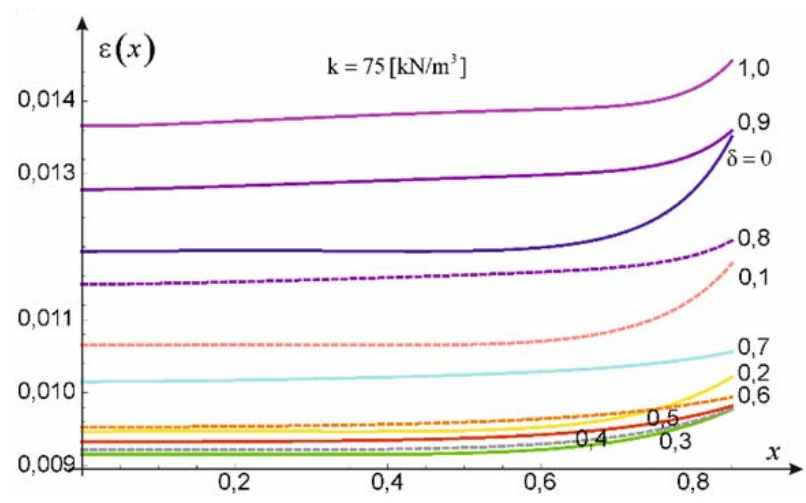

Rys. 10. Krzywe odkształcenia membrany dla różnych rozkładów obciążenia zastępczego reprezentowanego przez parametr $\delta: \mathrm{a}-$ dla $k=0 \mathrm{kN} \cdot \mathrm{m}^{-3}, \mathrm{~b}-$ dla $k=75 \mathrm{kN} \cdot \mathrm{m}^{-3}$

Fig. 10. Membrane strain curves for different equivalent load distributions represented by parameter $\delta$ : a - for $k=0$ $\mathrm{kN} \cdot \mathrm{m}^{-3}, \mathrm{~b}-$ for $k=75 \mathrm{kN} \cdot \mathrm{m}^{-3}$

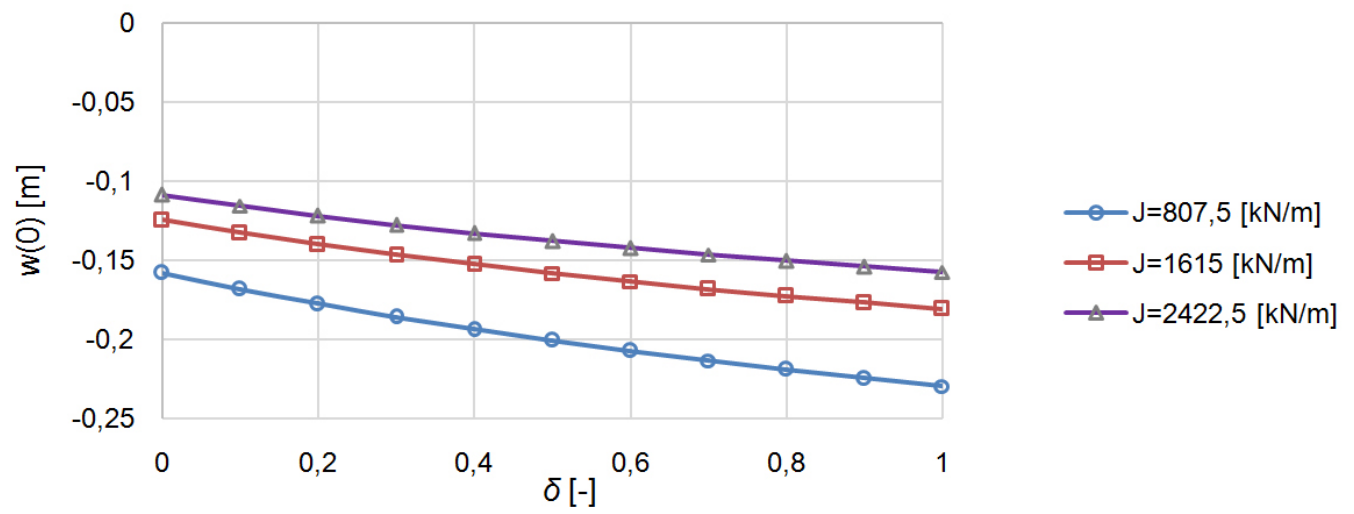

Rys. 11. Ugięcie membrany w połowie rozpiętości pomiędzy kolumnami $(x=0) \mathrm{w}$ funkcji parametru $\delta$ definiującego rozkład obciążenia zastępczego i różnych wartości sztywności membrany $J$

Fig. 11. Membrane deflection in the middle of the span between columns $(x=0)$ as a function of the parameter $\delta$ defining the equivalent load distribution and different values of membrane stiffness $J$ 
dej z analizowanych sztywności osiowej zbrojenia, przy danej sztywności zbrojenia, najmniejsze ugięcie membrany od obciążenia o $\delta=0$ jest ok. $45 \%$ mniejsze od największego ugięcia od obciążenia o $\delta=1$.

\section{PODSUMOWANIE}

W artykule przedstawiono charakter pracy membrany modelującej zbrojenie warstwy transmisyjnej nasypu w funkcji rozkładu obciążenia modelującego oddziaływanie od nasypu (parametr $\delta$ ), w funkcji sztywności podłoża gruntowego pomiędzy kolumnami oraz w funkcji sztywności zbrojenia. Dla wybranych rozkładów charakter ugięcia membrany jest zbieżny z zachowaniem zbrojenia obserwowanym w badaniach w skali naturalnej. Wartości odkształcenia odniesiono do wyników badań eksperymentalnych przy założeniu braku oddziaływania gruntu pomiędzy kolumnami $(k=0)$. W tym przypadku najmniejszy błą odwzorowania odkształceń uzyskano przy odwrotnym trójkątnym rozkładzie obciążenia, potwierdzając wnioski m.in. z pracy Van Eekelen (2015). Podkreślić jednak należy, że wniosek ten nie musi być prawdziwy po uwzględnieniu odporu od gruntu pomiędzy kolumnami (zwłaszcza o znacznej wartości). W opracowaniu pokazano, że zwiększanie sztywności gruntu istotnie zmienia charakter funkcji ugięcia, odkształcenia i siły normalnej w membranie.

\section{Indywidualny wkład autorów}

Opracowanie: B.G. i M.G.; metodologia: B.G i M.G.; oprogramowanie: M.G. i B.G.; walidacja: B.G. i M.G.; analiza formalna: B.G. i M.G.; badanie: B.G. i M.G.; zasoby: B.G. i M.G.; kompilacja i opracowanie danych: B.G. i M.G.; sporządzenie wstępnej wersji artykułu: B.G. i M.G.; redakcja i korekta artykułu: B.G.; wizualizacja: B.G.

Wszyscy autorzy zapoznali się z przeznaczoną do publikacji wersją manuskryptu.

\section{PIŚMIENNICTWO}

Almeida，M. S. S.，Marques， M. E. S., Almeida， M. C. F. i Mendonca, M. B. (2008). Performance on two low piled embankments with geogrids at Rio de Janeiro.
W Proceedings of the First Pan American Geosynthetics Conference and Exhibition, Cancun, Mexico (strony 1285-1295). Industrial Fabrics Association International.

Almeida, M. S. S., Ehrlich, M., Spotti A. P. i Marques, M. E. S. (2007). Embankment supported on piles with biaxial geogrids. Proceedings of the Institution of Civil Engineers - Geotechnical Engineering, 160 (4), 185-192.

Briançon, L. i Simon, B. (2012). Performance of Pile-Supported Embankment over Soft Soil: Full-Scale Experiment. Journal of Geotechnical and Geoenvironmental Engineering, 138, 551-561.

BS8006-1:2010. Code of practice for strengthened/reinforced soils and other fills. London: British Standards Institution.

Deutsche Gesellschaft für Geotechnik e.V. [DGGT] (2011). Recommendations for Design and Analysis of Earth Structures using Geosynthethic Reinforcements $E B G E O$. Monachium: Deutsche Gesellschaft für Geotechnik e.V./Ernst \& Sohn.

Gajewska, B. i Gajewski, M. (2019a). Approximation method for evaluation of strains and forces in LTP reinforcement of embankments on columns. IOP Conference Series: Materials Science and Engineering, 661 (1), 1-10. doi: 10.1088/1757-899X/661/1/012089

Gajewska, B. i Gajewski, M. (2019b). Reinforced columnsupported embankments: an approximation method for evaluating LTP reinforcement. W A. Szwed i i. D. Kamińska (red.), Theoretical foundation of civil engineering. Mechanics of materials and structures (strony 55-74). Warszawa: Oficyna Wydawnicza Politechniki Warszawskiej.

Hewlett, W. J. i Randolph, M. F. (1998). Analysis of piled embankments. Ground Engineering, 22 (3), 12-18.

Van Eekelen, S. J. M. (2015). Basal Reinforced Piled Embankments. Experiments, field studies and the development and validation of a new analytical design model (rozprawa doktorska). Technische Universiteit Delft, Delft.

Van Eekelen, S. J. M., Bezuijen, A. i Tol, A. F. van (2013). An analytical model for arching in piled embankments. Geotextiles and Geomembranes, 39, 78-102.

Van Eekelen, S. J. M. i Brugman, M. H. A. (2016). Basal Reinforced Piled Embankments. The Design Guideline. Delft: SBRCURnet/CRC Press.

Zaeske, D. (2001). Zur Wirkungsweise von unbewehrten und bewehrten mineralischen Tragschichten über pfahlartigen Gründungselementen. Schriftenreihe Geotechnik der Universität Kassel, 10. 


\section{THE EFFECT OF THE EQUIVALENT LOAD DISTRIBUTION ON THE BEHAVIOUR OF A MEMBRANE MODELLING THE REINFORCEMENT OF A LOAD TRANSFER PLATFORM}

\section{ABSTRACT}

The distribution of the equivalent load in the analysis of the reinforcement of an embankment load transfer platform on a soft soil reinforced with columns has an impact on the behaviour of the membrane modelling this reinforcement. Depending on the calculation model, triangular, uniform and inverse triangular distributions are commonly used. The paper analyses the behaviour of the membrane under the influence of 11 different load distributions. For all distributions, deflection curves and diagrams of tensile forces, deformation and the angle of rotation of the membrane were determined for the task of modelling the full-scale experiment. An analysis of the influence of the subgrade reaction modulus ( $k$ value) of the soft soil between the columns and the reinforcement stiffness on the membrane behaviour was also carried out. It was found that the adoption of one of the load distributions as suitable in every design situation is not always justified. As a result of the analyses, it has been shown that increasing soil stiffness ( $k$ value) significantly changes the nature of the function of deflection, deformation and normal force in the membrane, and this change depends on the distribution of the equivalent load.

Key words: rigid columns, load transfer platform, reinforcement of a load transfer platform, reinforcement behaviour, isotropic membranes 